\title{
Design a Single Stage AC to DC Converter for LED Driver With Power Factor Improvement
}

\author{
Sureshkumar A, Kalyanasundaram V, Vidyasagar S, George Fernandez, Vishnuram, P, \\ Suresh, $\mathbf{P}$
}

\begin{abstract}
This paper shows the design of a single switch LED driver circuit which is based on the operation of boost converter and flyback converter with power factor correction. In the proposed driver circuit, the boost converter is made to operate in DCM mode for achieving a high power factor and the flyback converter is used for isolating the input-output in order to provide safety. In addition to this, a snubber circuit is also designed for clamping the peak voltage of the main switch into low voltage and also to recycle the leakage inductor energy. A capacitor of low-voltage rating is made to function as the DC bus capacitor due to reason that some amount of the input power is conducted directly towards the output side; the amount of power remaining is then stored in the DC bus capacitor. In this way, the proposed LED driver circuit provides a power factor of greater value, i.e., above $0.95 \mathrm{PF}$ and also a high value of power conversion efficiency, i.e., above $90 \%$.
\end{abstract}

Keywords: AC to DC Converter, Power Factor correction (PFC), Light Emitting Diode (LED), Flyback Converter, Snubber Circuit, DC Bus Capacitor.

\section{INTRODUCTION}

The effect due to the presence of greenhouse gases and the petroleum crisis across the world has made the humans to emphasis more and more on efficient energy utilization. One the most common and convenient energy resources known to mankind is electricity. The electrical energy is easily accessible to the users through solar cells, wall plugs, batteries, etc. Electrical applications in today's worlds are basically omnipresent, for example lightning and motor applications. The total power consumption of these applications account for over more than $16 \%$ of the overall electrical energy consumption, which was to equivalent to approximately 587 billion $\mathrm{kWh}$ in the year 2001 [1]. Recently, the awareness towards the sustainability problems of the world has forced the governments and committees

Revised Version Manuscript Received on 10, September 2019.

Sureshkumar A, Assistant Professor, Department of Electrical and Electronics Engineering, SRMIST, Kattankulathur, Chennai, Tamil Nadu, India.(Email: sureshkumarask2@gmail.com)

Kalyanasundaram V Assistant Professor, Department of Electrical an Electronics Engineering, SRMIST, Kattankulathur, Chennai, Tamil Nadu, India.

Vidyasagar S, Assistant Professor, Department of Electrical and Electronics Engineering, SRMIST, Kattankulathur, Chennai, Tamil Nadu, India.

George Fernandez, Assistant Professor, Department of Electrical and Electronics Engineering, SRMIST, Kattankulathur, Chennai, Tamil Nadu, India

Vishnuram, P, Assistant Professor, Department of Electrical and Electronics Engineering, SRMIST, Kattankulathur, Chennai, Tamil Nadu, India.

Suresh, P, Assistant Professor, Department of Electrical and Electronics Engineering, SRMIST, Kattankulathur, Chennai, Tamil Nadu, India. across the globe to begin the search for ways of promoting sustainability.

By increasing the efficiency of the lightning applications, a sufficient amount of electrical energy could be saved. The efficiency of an electrical appliance not only depends on the lightning sources (materials) but also takes into consideration the driving circuits of the system. In comparision to other lightning sources such as high intensity discharge lamps, fluorescent lamps and cold cathode fluorescent lamps, the LED has tremendous advantages of being devices which are mercury free, ultra long lifetime(above 55000h) and low voltage driving [2]-[4]. It has also been reported that the LED can also be applied to general lightning solutions [5]-[10], while successfully replacing halogen lamps and incandescent lamps.

Generally, the design of the driving circuit of LED affects its energy efficiency as significant to the lightning sources and is used to increase its efficiency through proper driving circuits. In order to drive LEDs a DC voltage is required, so conversion of $\mathrm{AC}$ voltage to $\mathrm{DC}$ voltage is required. Traditional AC to DC switching converters were basically composed of a bulk capacitor, a bridge diode rectifier and a DC to DC switching converter; this design had various drawbacks such as poor performance in power factor(PF) and harmonic distortion [6]. Initial LED drivers had two control circuits and two switches which are present in each stage, making it less efficient and more expensive. In order to overcome the problems of the initial driving circuits of complying with the regulations on harmonics present in the current and increasing the power factor, an additional PFC stage is cascaded in front of the initial converter. Boost PFC circuits are being used most commonly due to the fact that they can provide power factor of high value by using just a simple control circuitry and simple structure. In order to increase the efficiency and reducing the cost, single stage converter circuits are being developed over the past few years [11]-[26]. Despite of the various advantages, the efficiency of these single staged converters are not high enough (70\%). However, when applying isolated transformers, the efficiency of the system is highly encumbered with the leakage inductance.

In an effort of solving these drawbacks, a single-stage AC-DC LED driver which is designed on the basis of a boost-flyback PFC converter with a lossless snubber as shown in figure 1 has been proposed in this paper. As the 


\section{DESIGN A SINGLE STAGE AC TO DC CONVERTER FOR LED DRIVER WITH POWER FACTOR IMPROVEMENT}

proposed LED driving circuit is based on the boost-flyback structure, a power factor of higher value is obtained based on the boost PFC, which continuously operates in the discontinuous conduction mode. As the energy required to fulfill the load is comparatively low enough because of the light loads, we prefer DCM for light loads.

Due to the presence of snubber circuit which has no losses, the leakage energy of the inductor present is being recycled into the DC-DC flyback circuit and the peak voltage spike in the main switch has been clamped to a low voltage value.

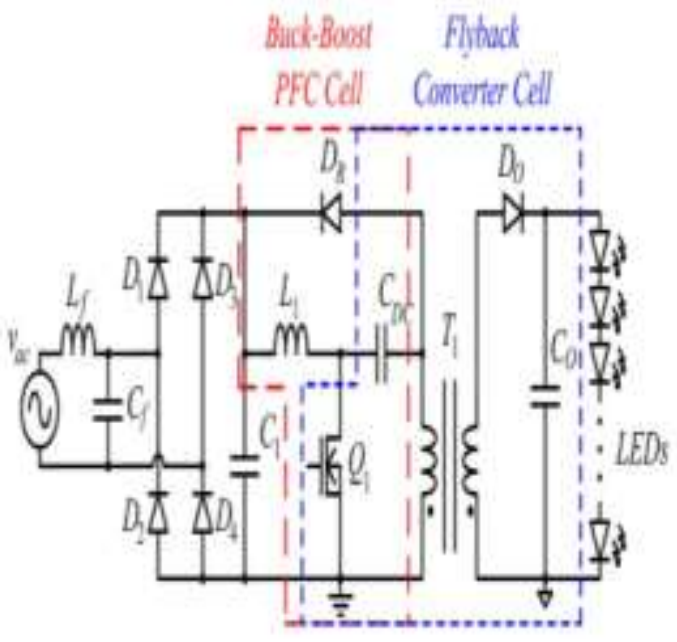

Fig.1. Basic Circuit Diagram

The DC bus capacitor has been divided into two capacitors, the first one being the snubber capacitor and the other one being DC bus capacitor.. Therefore, the energy conversion efficiency has been removed in addition to a reduction in voltage of DC bus capacitor. The LED driver circuit proposed in this paper provides a high power factor in order to achieve a high power conversion efficiency.

\section{PROPOSED SYSTEM}

In the driver circuit proposed, the system consists of Lf and $\mathrm{Cf}$ as shown in figure 2 . The boost PFC converter comprises of the main switch $\mathrm{S} 1$, the boost conductor $\mathrm{Lb}$ and the reverse blocking diode $\mathrm{Db}$. The reverse blocking diode restricts the flow of reverse current through the boost inductor for Direct Conduction Mode operation. The flyback converter present in the system consists of the DC bus capacitor Cdc, the coupled inductor $\mathrm{T} 1$, the shared switch $\mathrm{S} 1$, the output capacitor $\mathrm{C} 0$ and the output diode D0. The lossless snubber circuit is comprised of C1,L1 and D1.

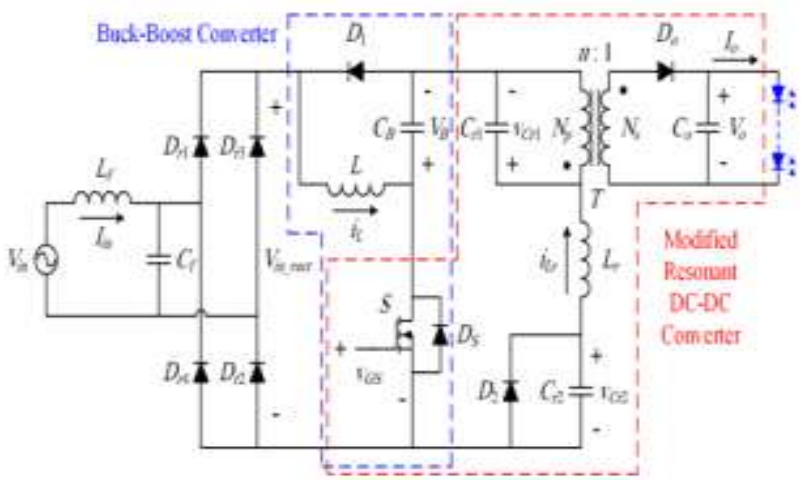

Fig.2. Proposed Driving Circuit
The capacitor CS1 is used as the parasitic output capacitance of $\mathrm{S} 1$. The coupled inductor $\mathrm{T} 1$ contains a magnetizing inductor $\mathrm{Lm}$ and a leakage inductor Lk having a turn ratio of $n: 1(n=N p / N s)$.. In accordance to the volt-second balance law, as the average voltage across the inductor at the steady state should be equal to zero, the voltage present across the $\mathrm{C} 1$ and $\mathrm{Cdc}$ sholud be automatically equal to Vdc. The capacitances of $\mathrm{C} 1, \mathrm{Cdc}$ and $\mathrm{C} 0$ have a large value such that their voltages are considered constant.

Whenever a power failure occurs across the system, the power is automatically delivered to the load by the help of a battery. The PNP transistor starts to act as a switch. When the mains power is $\mathrm{ON}$, the positive part of the supply is kept at the base of the transistor, keeping the transistor in OFF condition.

\section{MODES OF OPERATION}

Before mode 1, all the seminconductor devices are assumed to be off. The resonant capacitors $\mathrm{C}_{\mathrm{r} 1}$ and $\mathrm{C}_{\mathrm{r} 2}$ have voltages equal to $-\mathrm{V}_{1}$ and $\mathrm{V}_{2}$ respectively.

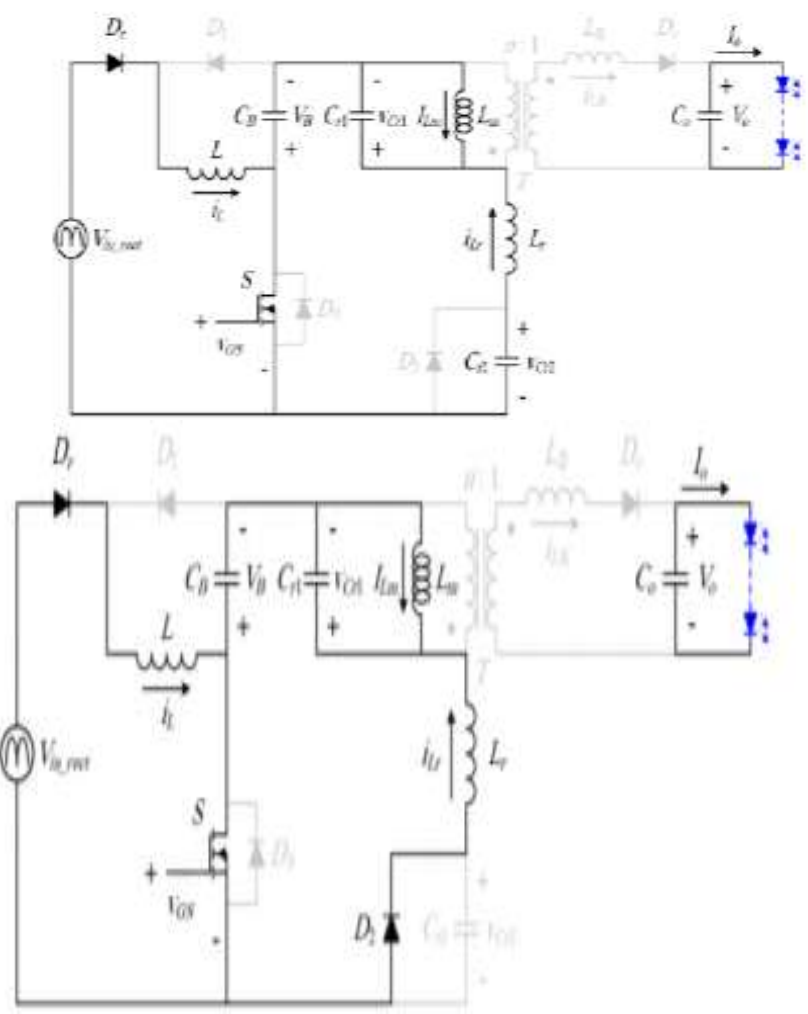

(a)

(b)

Fig.3. (a) Mode 1 (b) Mode 2

In mode 1 , fig 3 shows the switch $S$ is turned on. The inductor $\mathrm{L}$ carries a voltage $\mathrm{V}_{\text {in_rect }}$, due to this $\mathrm{i}_{\mathrm{L}}$ increases from zero linearly. There is an occurrence of a resonance between $\mathrm{L}_{\mathrm{r}}, \mathrm{L}_{\mathrm{m}}, \mathrm{C}_{\mathrm{r} 1}$ and $\mathrm{C}_{\mathrm{r} 2}$. This resonance occurrence maakes $\mathrm{V}_{\mathrm{Cr} 2}$ reduce to a value of zero. There is a smooth increase in the currents across the inductors which ensures the ZCS turn on condition of the switch $\mathrm{S}$. If $\mathrm{L}_{\mathrm{m}}$ is considered to be a large value, the current across it will become much smaller than the resonant current $\mathrm{i}_{\mathrm{Lr}}$, this small value of 
inductor current can be neglected. Hence, the resonant capacitors $\mathrm{C}_{\mathrm{r} 1}$ and $\mathrm{C}_{\mathrm{r} 2}$ are connected in a series connection. The effect of $\mathrm{L}_{\mathrm{m}}$ on the resonant currents and the voltages in the other operating modes are also ignored. In mode $1, \mathrm{i}_{\mathrm{Lr}}$ and $\mathrm{V}_{\mathrm{Cr} 2}$ can be written as

$$
\mathrm{I}_{\mathrm{Lr}}(\mathrm{t})=\mathrm{V}_{1}+\mathrm{V}_{2}+\mathrm{V}_{\mathrm{s}} / 0.707 \mathrm{Z}_{\mathrm{r} 1} * \sin \left(1.414 \mathrm{~W}_{\mathrm{r} 1}\left(\mathrm{t}-\mathrm{t}_{\mathrm{o}}\right)\right)
$$

$\mathrm{V}_{\mathrm{Cr} 2}(\mathrm{t})=\mathrm{V}_{2}-\mathrm{V}_{1}+\mathrm{V}_{2}+\mathrm{V}_{\mathrm{s}} / 2 *\left[1-\cos \left(1.414 \mathrm{~W}_{\mathrm{r} 1}\left(\mathrm{t}-\mathrm{t}_{\mathrm{o}}\right)\right)\right]$

If $\mathrm{V}_{2}$ is considered to be equal to $\mathrm{V}_{1}+\mathrm{V}_{\mathrm{B}}$, then according to (1) and (2) $i_{\mathrm{Lr}}$ will reach to its peak at the same time when the voltage across $\mathrm{C}_{\mathrm{r} 2}$ becomes zero

$$
\begin{gathered}
\mathrm{i}_{\mathrm{Lr}}(\mathrm{t})=1.414 \mathrm{~V}_{2} / \mathrm{Z}_{\mathrm{r} 1} * \sin \left(1.414 \mathrm{~W}_{\mathrm{r} 1}\left(\mathrm{t}-\mathrm{t}_{\mathrm{o}}\right)\right) \\
\mathrm{v}_{\mathrm{Cr} 1}(\mathrm{t})=\mathrm{V}_{2}\left[1-\cos \left(1.414 \mathrm{~W}_{\mathrm{r} 1}\left(\mathrm{t}-\mathrm{t}_{\mathrm{o}}\right)\right)\right]-\mathrm{V}_{1} \\
\mathrm{v}_{\mathrm{Cr} 2}(\mathrm{t})=\mathrm{V}_{2} \cos \left(1.414 \mathrm{~W}_{\mathrm{r} 1}\left(\mathrm{t}-\mathrm{t}_{\mathrm{o}}\right)\right)
\end{gathered}
$$

Mode 1 ends when the voltage $\mathrm{V}_{\mathrm{Cr} 2}$ reaches a value of zero. In mode 2 , the diode $\mathrm{D}_{2}$ is turned on under a zero voltage switching condition. Due to this $\mathrm{L}_{\mathrm{r}}$ and $\mathrm{C}_{\mathrm{r} 1}$ continues to resonate and the value of $\mathrm{V}_{\mathrm{Cr} 1}$ increases. When $\mathrm{V}_{\mathrm{Cr} 1}$ obtains a value of $\mathrm{nV}_{\mathrm{o}}$, the output diode voltage reaches a value of zero and mode 2 ends

$$
\begin{aligned}
\mathrm{i}_{\mathrm{Lr}}(\mathrm{t}) & =1.414 \mathrm{~V}_{2} / \mathrm{Z}_{\mathrm{r} 1} * \cos \left(\mathrm{W}_{\mathrm{r} 1}\left(\mathrm{t}-\mathrm{t}_{1}\right)\right) \\
\mathrm{v}_{\mathrm{Cr} 1}(\mathrm{t}) & =\mathrm{V}_{\mathrm{B}}+1.414 \mathrm{~V}_{2} \sin \left(\mathrm{w}_{\mathrm{r} 1}\left(\mathrm{t}-\mathrm{t}_{1}\right)\right)
\end{aligned}
$$

In mode 3 , the output diode starts to conduct under the ZVZCS condition and the inductor $\mathrm{L}_{\mathrm{lk}}$ starts to resonance.

$$
\begin{gathered}
\mathrm{L}_{\mathrm{Lq}} / \mathrm{t}(\mathrm{t})=\left(1-\mathrm{L}_{\mathrm{eq}} / \mathrm{L}_{\mathrm{r}}\right) \mathrm{i}_{\mathrm{Lr}}\left(\mathrm{t}_{2}\right)-\left(\mathrm{nV}_{\mathrm{o}}-\mathrm{V}_{\mathrm{s}}\right) \mathrm{L}_{\mathrm{eq}} / \mathrm{W}_{\mathrm{r} 3} \mathrm{~L}_{\mathrm{r}}^{2} * \sin \left(\mathrm{W}_{\mathrm{r} 3}\left(\mathrm{t}-\mathrm{t}_{2}\right)\right)+ \\
\mathrm{L}_{\mathrm{r}} * \mathrm{i}_{\mathrm{Lr}}\left(\mathrm{t}_{2}\right) \cos \left(\mathrm{W}_{\mathrm{r} 3}\left(\mathrm{t}-\mathrm{t}_{2}\right)\right)+\mathrm{nV}_{\mathrm{o}}-\mathrm{V}_{\mathrm{s}} / \mathrm{L}_{\mathrm{r}}+\mathrm{n}^{2} \mathrm{~L}_{\mathrm{s}}\left(\mathrm{t}-\mathrm{t}_{2}\right)
\end{gathered}
$$

$$
\mathrm{v}_{\mathrm{Cr} 1}(\mathrm{t})=\mathrm{V}_{\mathrm{B}}+\mathrm{Z}_{\mathrm{r} 1} \mathrm{i}_{\mathrm{Lr}}\left(\mathrm{t}_{2}\right) \sin \left(\mathrm{W}_{\mathrm{r} 1}\left(\mathrm{t}-\mathrm{t}_{2}\right)\right)+\left(\mathrm{nV}_{\mathrm{o}}-\mathrm{V}_{\mathrm{B}}\right) \cos \left(\mathrm{W}_{\mathrm{r} 1}\left(\mathrm{t}-\mathrm{t}_{2}\right)\right)
$$
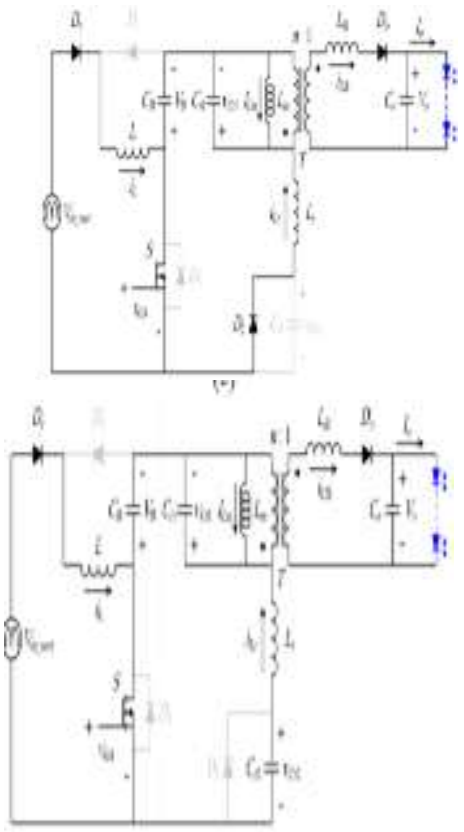

(a)

Fig.4. (a) Mode 3 (b) Mode 4

(b)

Mode 3 ends when the value of resonant current $i_{\text {Lr }}$ attains zero. In mode 4 , the direction of the current $i_{L r}$ is inversed and the diode $\mathrm{D}_{2}$ is turned off under the ZVZCS condition. The capacitor $\mathrm{C}_{\mathrm{r} 2}$ continues to resonate.
In this mode $i_{L r}$ has two frequency components.

$$
\begin{aligned}
& \mathrm{i}_{\mathrm{Lr}}(\mathrm{t})=-\mathrm{v}_{\mathrm{Cr} 1}\left(\mathrm{t}_{3}\right)-\mathrm{V}_{\mathrm{B}} / 1.414 \mathrm{Z}_{\mathrm{r} 1} * \sin \left(1.414 \mathrm{~W}_{\mathrm{r} 1}\left(\mathrm{t}-\mathrm{t}_{3}\right)\right) \\
& \mathrm{v}_{\mathrm{Cr} 1}(\mathrm{t})=\mathrm{V}_{\mathrm{B}}+\mathrm{v}_{\mathrm{Cr} 1}\left(\mathrm{t}_{3}\right)-\mathrm{V}_{\mathrm{B}} / 2 *\left[1+\cos \left(1.414 \mathrm{~W}_{\mathrm{r} 1}\left(\mathrm{t}-\mathrm{t}_{3}\right)\right)\right] \\
& \mathrm{v}_{\mathrm{Cr} 2}(\mathrm{t})=\mathrm{v}_{\mathrm{Cr} 1}\left(\mathrm{t}_{3}\right)-\mathrm{V}_{\mathrm{B}} / 2 *\left[1-\cos \left(1.414 \mathrm{~W}_{\mathrm{r} 1}\left(\mathrm{t}-\mathrm{t}_{3}\right)\right)\right] \\
& \mathrm{i}_{\mathrm{Llk}}(\mathrm{t})=\mathrm{i}_{\mathrm{Llk}}\left(\mathrm{t}_{3}\right) \cos \left(\mathrm{W}_{\mathrm{r} 2} / 1.414 *\left(\mathrm{t}-\mathrm{t}_{3}\right)\right)
\end{aligned}
$$

There is a reduction in the current through the switch due to the negative current of $i_{\mathrm{Lr}}$. Mode 4 ends when the value of $\mathrm{i}_{\mathrm{Lr}}$ is equal to the value of $\mathrm{i}_{\mathrm{L}}$, due to this the switch current attains a value of zero.

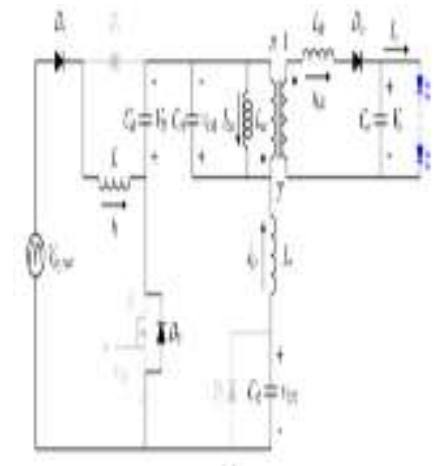

(a)

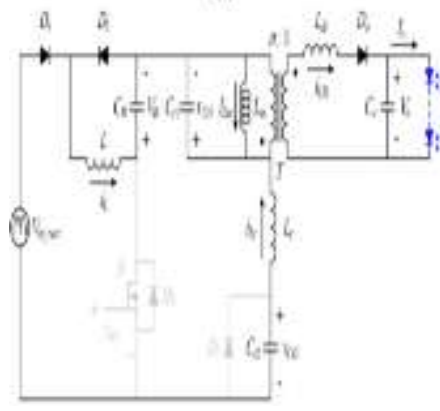

Fig.5. (a) Mode 5 (b) Mode 6

(b)

In mode 5 , the body diode of the switch $\mathrm{D}_{\mathrm{s}}$ is turned on,due to the value of current $i_{L r}$ exceeding the value of $i_{L}$. The $L_{r}, C_{r 1}$ , $\mathrm{C}_{\mathrm{r} 2}$ and $\mathrm{L}_{\mathrm{lk}}$ continues to resonate until the value of current $\mathrm{D}_{\mathrm{s}}$ reaches to zero. The switch $\mathrm{S}$ is turned off ny the ZVZCS condition.

he ZCS turn on condition of $\mathrm{D}_{1}$ is provided due to the reduction of $i_{L r}$ at a faster rate as compared to $i_{L}$. at the end of mode 6 , the voltage $V_{\mathrm{Cr} 2}$ is increased to $V_{2}$ and the current $i_{\mathrm{Lr}}$ approches zero.

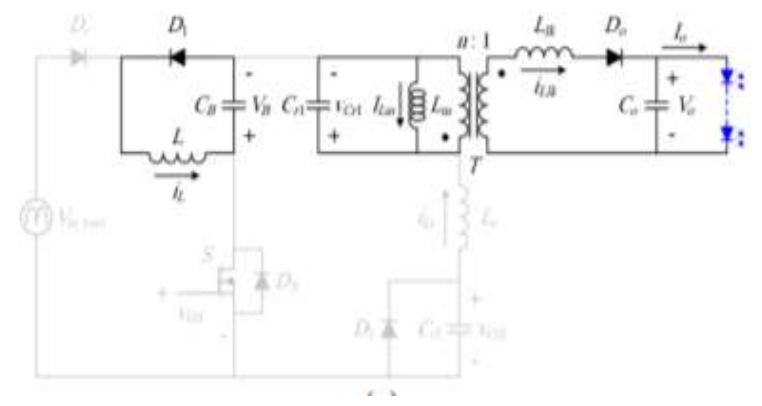

Published By: 


\section{DESIGN A SINGLE STAGE AC TO DC CONVERTER FOR LED DRIVER WITH POWER FACTOR \\ IMPROVEMENT}

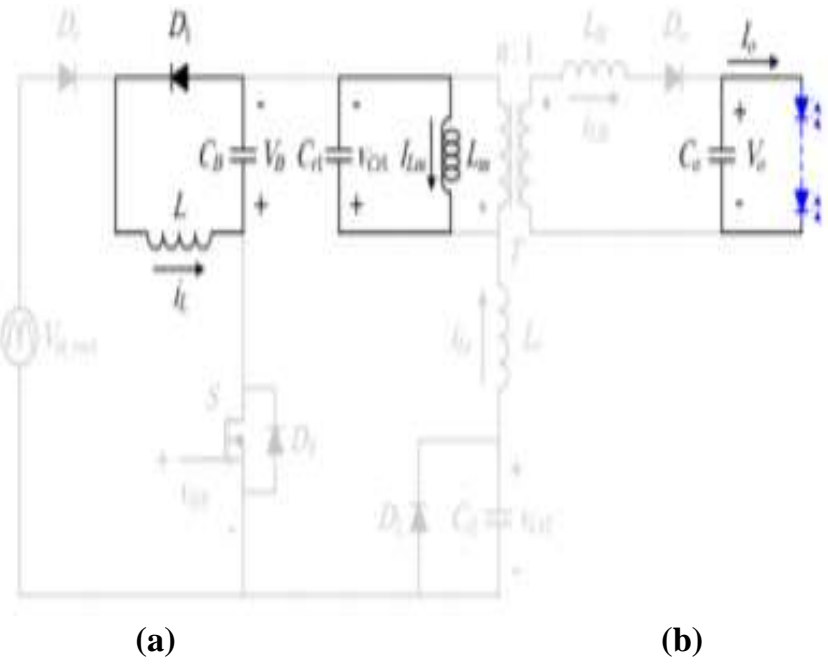

Fig.6. (a) Mode 7 (b) Mode 8

In mode 7, due to the resonance of the $\mathrm{C}_{\mathrm{r} 1}$ and $\mathrm{L}_{\mathrm{lk}}$, the voltage $\mathrm{V}_{\mathrm{Cr} 1}$ decreases. The resonance of the $\mathrm{C}_{\mathrm{r} 1}$ and $\mathrm{L}_{\mathrm{lk}}$ continues till the output diode is turned off under ZCS condition and the current $\mathrm{i}_{\mathrm{Llk}}$ reaches zero.

$$
\mathrm{i}_{\mathrm{Llk}}(\mathrm{t})=-\mathrm{n}\left[\mathrm{nV} \mathrm{V}_{\mathrm{o}}-\mathrm{v}_{\mathrm{Cr} 1}\left(\mathrm{t}_{6}\right)\right] / \mathrm{Z}_{\mathrm{r} 2} * \sin \left(\mathrm{W}_{\mathrm{r} 2}\left(\mathrm{t}-\mathrm{t}_{6}\right)\right)+\mathrm{i}_{\mathrm{Llk}}\left(\mathrm{t}_{6}\right) \cos \left(\mathrm{W}_{\mathrm{r} 2}(\mathrm{t}-\mathrm{t}\right.
$$
6))

$\mathrm{v}_{\mathrm{Cr} 1}=\mathrm{nV}_{\mathrm{o}}-\mathrm{Z}_{\mathrm{r} 2} \mathrm{i}_{\mathrm{Llk}}\left(\mathrm{t}_{6}\right) / \mathrm{n} * \sin \left(\mathrm{W}_{\mathrm{r} 2}\left(\mathrm{t}-\mathrm{t}_{6}\right)\right)-\left[\mathrm{nV}_{\mathrm{o}}\right.$ $\left.\mathrm{v}_{\mathrm{Cr} 1}\left(\mathrm{t}_{6}\right)\right] \cos \left(\mathrm{W}_{\mathrm{r} 2}\left(\mathrm{t}-\mathrm{t}_{6}\right)\right)$

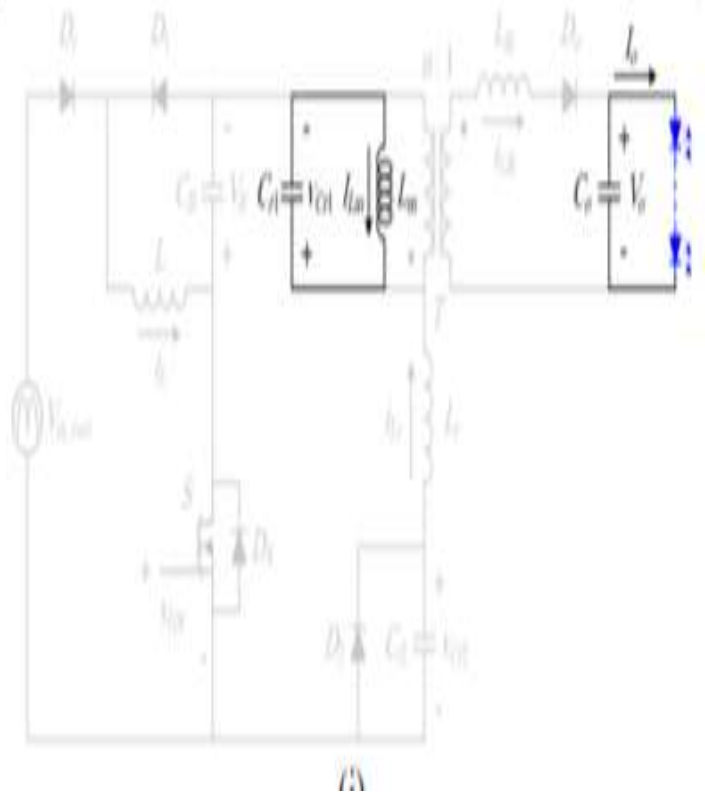

Fig.7. Mode 9

\section{SIMULATION}

The driver circuit proposed in this paper has been simulated by the help of Matlab software. The input AC voltage at the source is given to be $100 \mathrm{~V}$ with a frequency of $50 \mathrm{~Hz}$. An inductor with an inductance value of $1 * 10^{-3} \mathrm{H}$ and a capacitor with capacitance of $1200 * 10^{-6} \mathrm{~F}$ have been connected across the input voltage source. A diode bridge rectifier is then connected to convert the AC input to DC.

The bridge rectifier consists of four diodes each having a resistance of $1 * 10^{-3} \mathrm{ohms}$ with a forward voltage of $0.8 \mathrm{~V}$. The snubber resistance present in each of the diode is 500 
ohms and the snubber capacitance value is $250 * 10^{-9} \mathrm{~F}$. A boost converter is connected to the bridge rectifier with an inductor of inductance $1 * 10^{-6} \mathrm{H}$ and a capacitor of capacitance $1200^{*} 10^{-6} \mathrm{~F}$. The diode present in the boost converter has a resistance of $1 * 10^{-3}$ ohms with a forward voltage of $0.8 \mathrm{~V}$. This diode present in the boost converter also has a snubber resistance of 500 ohms and a snubber capacitance of $250 * 10^{-9} \mathrm{~F}$. The pulse generator in the boost converter generates an amplitude of 1 metre with a time period of $2 * 10^{-5}$ seconds. The pulse width by the pulse generator is given to be $45 \mathrm{~Hz}$ with a zero phase delay. The MOSFET present in the boost converter has a FET resistance of $0.1 \mathrm{ohms}$ and the internal diode resistance of $0.01 \mathrm{ohms}$. The snubber resistance value of the MOSFET is given to be $1 * 10^{-5}$ ohms.

The boost converter is then connected to a snubber circuit through an inductor of inductance $3 * 10^{-6} \mathrm{H}$ and a capacitor of capacitance $12 * 10^{-6} \mathrm{~F}$. The diode present in the snubber circuit has a resistance of $1 * 10^{-3} \mathrm{ohms}$ with a forward voltage of $0.8 \mathrm{~V}$. The diode has a snubber resistance of $500 \mathrm{ohms}$ and a snubber capacitance of $250 * 10^{-9} \mathrm{~F}$. The snubber circuit also has a capacitor with a capacitance of $1 * 10^{-6} \mathrm{~F}$. The snubber circuit is then connected to the flyback circuit through a linear transformer.

The linear transformer has nominal power of $100 \mathrm{VA}$ and frequency of $10000 \mathrm{~Hz}$. The winding 1 has a voltage of $100 \mathrm{~V}$ and the winding 2 has a voltage of $400 \mathrm{~V}$. The magnetizing resistance of the linear transformer is given to be $1.0805^{*} 10^{6}$ ohm and the magnetizing inductance is given to be $2866 \mathrm{H}$. The flyback circuit consists of a resistor of resistance 1000 ohms and a capacitor of capacitance $1200 * 10^{-6} \mathrm{~F}$. The diode in the flyback circuit has a resistance of $1 * 10^{-3} \mathrm{ohms}$ with a forward voltage of $0.8 \mathrm{~V}$. The snubber resistance of the diode is $500 \mathrm{ohms}$ while the snubber capacitance is $250 * 10^{-9} \mathrm{~F}$. The LED driver circuit proposed in the paper has been simulated in the Matlab software using these values and the output was obtained as shown in figure 9 .

\section{ANALYSIS OF THE CIRCUIT \& RESULTS}

In the section concerned, LED driver circuit has been analyzed. The sinusoidal waveform line voltage has an amplitude $\mathrm{V}_{\mathrm{m}}$ and angular frequency $\mathrm{w}_{\mathrm{l}}$

Eliminating the high frequency harmonics of the PFC cell's input current with the help of input current, the line current $\mathrm{I}_{\text {in }}$ mentioned above is the average of input current pulses over each switching period is given by,

$$
I_{\text {in }}(t)=1 / T_{S} * 1 / 2 * I_{L p}(t) t_{R l}
$$

$\mathrm{I}_{\mathrm{Lp}}=$ peak current of inductor $\mathrm{L}$ in every switching cycle $\mathrm{t}_{\mathrm{rL}}=$ rise time of $\mathrm{I}$ that is time duration of modes 1 to 5 .

$t_{R l}$ is assumed equal to $D T_{S}$ where $D$ is called the switch duty cycle. Hence using eqn.(15)

$$
\mathrm{I}_{\text {in }}(\mathrm{t})=\mathrm{D}^{2} \mathrm{~T}_{\mathrm{S}} \mathrm{V}_{\mathrm{m}} / 2 \mathrm{~L} * \sin \left(\mathrm{w}_{\mathrm{l}} \mathrm{t}\right)
$$

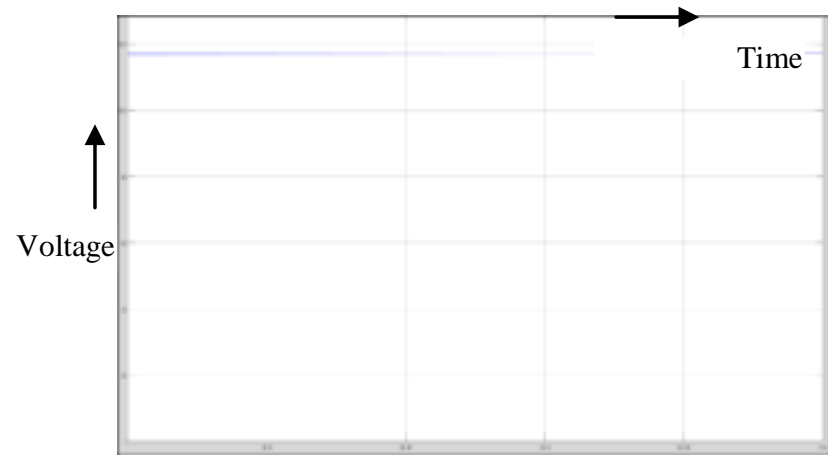

Fig.9. Output Voltage wave form simulation

By the help of eqn.(16),it can be considered that the line current is in phase with line voltage, provided switch duty cycle $\mathrm{D}$ is constant.

Hence, input power $\mathrm{P}_{\text {in }}$ can be calculated with the help of using line current equation.

The inductance value $\mathrm{L}$ is to be designed such that the input power required can be provided with the desired duty cycle and switching frequency.

Here the output power $\mathrm{P}_{\mathrm{O}}$ is equal to average input power. Hence value of $\mathrm{L}$ is given by,

$$
\mathrm{L}=\mathrm{D}^{2} \mathrm{~V}_{\mathrm{m}}^{2} / 4 \mathrm{P}_{\mathrm{O}} \mathrm{f}_{\mathrm{s}}
$$

During mode 5 the circuit is turned off. Hence the on time value of switch is expressed with the help of $T_{r 1}$ of $L_{r}$ and $\mathrm{C}_{\mathrm{r}}$, where $\mathrm{T}_{\mathrm{r} 1}$ is resonant period. Hence

$$
\mathrm{DT}_{\mathrm{s}}=1 / 4 * 0.707 * \mathrm{~T}_{\mathrm{r} 1}+1 / 4 * \mathrm{~T}_{\mathrm{r} 1}+1 / 4 \mathrm{~T}_{\mathrm{r} 1} * 0.707
$$

According to eqn.(18), $\mathrm{T}_{\mathrm{r} 1}$ can be obtained with the help of $\mathrm{DT}_{\mathrm{s}}$. Now value of $\mathrm{I}_{\mathrm{Lp}}$ in accordance to above equation is $\mathrm{V}_{\mathrm{m}} \mathrm{DT}_{\mathrm{s}} / \mathrm{L}$

Value of $i_{\text {Lr }}$ negative peak is equal to,

$$
\left|\mathrm{I}_{\mathrm{Lr} \_ \text {np }}\right|=\mathrm{V}_{2} / 0.707 \mathrm{Z}_{\mathrm{r} 1}
$$

Hence by integrating $i_{L r}, V_{2}$ is obtained as,

$$
\mathrm{V}_{2}=\mathrm{P}_{\mathrm{O}} \mathrm{T}_{\mathrm{S}} / 0.707 \mathrm{C}_{\mathrm{r}} \mathrm{V}_{\mathrm{B}}
$$

$\mathrm{I}_{\mathrm{Lm}}$ is obtained by considering average current of $\mathrm{C}_{\mathrm{r} 1}$ equal to zero. Hence, by using eqn.(20), we get

$$
\mathrm{I}_{\mathrm{Lm}}=\left(\mathrm{I}_{\mathrm{o}} / \mathrm{n}\right)-\left(\mathrm{P}_{\mathrm{o}} / \mathrm{V}_{\mathrm{B}}\right)
$$

Now the magnetizing inductance of the transformer is parallel to the $\mathrm{C}_{\mathrm{r} 1}$. Integrating $\mathrm{V}_{\mathrm{Cr} 1}$ during mode 1 yields,

$$
3.14\left(\mathrm{~V}_{2}-\mathrm{V}_{1}\right) / 2.82 \mathrm{~W}_{\mathrm{r} 1}-\mathrm{V}_{2} / 1.41 \mathrm{~W}_{\mathrm{r} 1}
$$

Integration of $\mathrm{V}_{\mathrm{Cr} 1}$ gives,

$$
\mathrm{nV}_{\mathrm{o}} \mathrm{T}_{\mathrm{r} 2} / 2
$$

Now $\mathrm{T}_{\mathrm{C}}$ is the time duration of mode 8 and 9 . Hence

$$
\mathrm{T}_{\mathrm{C}}=\mathrm{T}_{\mathrm{s}}-\mathrm{T}_{\mathrm{r} 1} / 5.65-\mathrm{T}_{\mathrm{r} 2} / 2
$$

Using eqn.(23), appropriate value of $\mathrm{C}_{\mathrm{r}}$ is selected such that,

$$
\left|\mathrm{I}_{\mathrm{Lr}_{-} \mathrm{np}}\right|>\mathrm{V}_{\mathrm{m}} \mathrm{DT}_{\mathrm{s}} / \mathrm{L}
$$

\section{HARDWARE}

The hardware consists of a combination of a transformer, rectifier and a filter as shown in figure 10. Here the transformer used is a step down transformer. Firstly, the step down voltage is used to convert the $230 \mathrm{~V}$ AC into $12 \mathrm{~V}$ AC. The stepped down voltage of $12 \mathrm{~V}$ AC has an RMS value of $17 \mathrm{~V}$, but the voltage required by the circuit is only $5 \mathrm{~V}$. So 


\section{DESIGN A SINGLE STAGE AC TO DC CONVERTER FOR LED DRIVER WITH POWER FACTOR IMPROVEMENT}

for this purpose, the $17 \mathrm{~V} \mathrm{AC}$ is firstly converted into $\mathrm{DC}$ and then it is stepped down to $5 \mathrm{~V}$ DC voltage. AC voltage can be converted to DC with the help of rectifiers. The rectifier used here is a bridge rectifier due to its advantage over half wave and full wave rectifier.

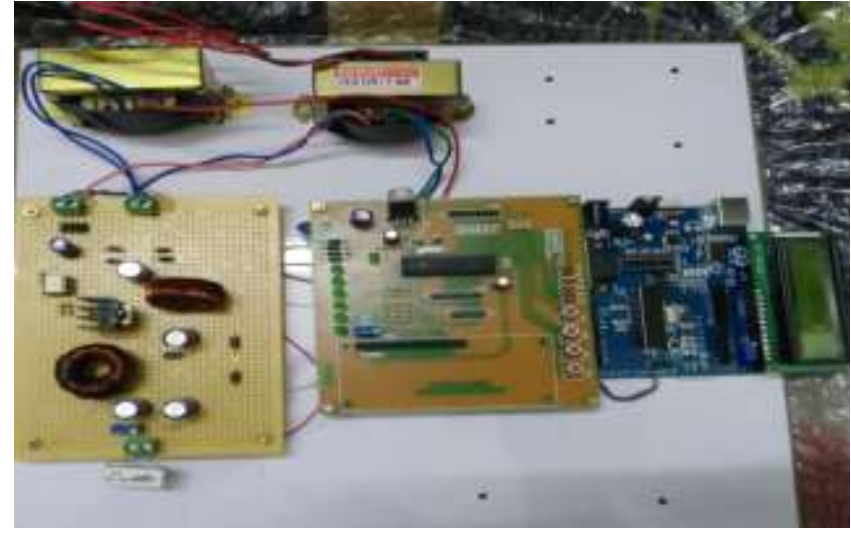

Fig.10. Hardware

Table - Hardware Components

\begin{tabular}{|l|l|}
\hline \multicolumn{1}{|c|}{ Component } & \multicolumn{1}{|c|}{ Rating } \\
\hline Linear Transformer & $230 \mathrm{~V} \mathrm{AC}, 12 \mathrm{~V} \mathrm{DC}, 1 \mathrm{~A}$ \\
\hline Resistors & $1 * 10^{-3}$ ohms \\
\hline Capacitors & $1200^{-6} 10^{-6} \mathrm{~F}$ \\
\hline Inductors & $2866 \mathrm{H}$ \\
\hline DSPIC Microcontroller & PIC32MX250F128B-50I/S \\
& $\mathrm{P}$ \\
\hline Arduino UNO & R3 CH340G \\
& ATMEGA328P \\
\hline LED Display & $\begin{array}{l}\text { Blacklight } \\
\end{array}$ \\
\hline
\end{tabular}

Before the $15 \mathrm{~V}$ DC is converted into $5 \mathrm{~V} \mathrm{DC}$, it is necessary to obtain the pure DC voltage. The output of the bridge rectifier contains a considerable amount of ripples. These ripples can be eliminated with the help of capacitor filter.

Now, the input voltage is increased from zero to the peak value and the supply voltage reduces from peak value to zero. Due to the continuous charging and discharging of the capacitor, the DC output supply which contain ripples gets converted into pure DC supply.

\section{CONCLUSION}

In this paper, a single switch AC-DC LED driver circuit which is based on a boost converter and a flyback converter with a lossless snubber circuit has been proposed. A power factor of high value is achieved by the help of boost PFC converter operating in Direct Conduction Mode. In the flyback converter, the peak voltage stress of the switch gets clamped and there is a recycling of the leakage inductor energy. This takes place because of the presence of a lossless snubber circuit in the system. The DC capacitor gets spilt into two different capacitors. In addition to this, some amount of input power of the boost inductor gets directly conducted to the output due to the usage of a low voltage rating capacitor. Hence, the power factor is corrected and due to which the overall efficiency of the system is improved.

\section{REFERENCES}

1. Z. Ye, F. Greenfeld, and Z. Liang, "A topology study of single-phase offline $\mathrm{AC} / \mathrm{DC}$ converters for high brightness white LED lighting with powerfactorpre-regulationandbrightnessdimmable,"inPro c.IEEE34th IECON, 2008, pp. 1961-1967.

2. C. Y. Wu, T. F. Wu, J. R. Tsai, Y. M. Chen, and C. C. Chen, "Multistring LED backlight driving system for LCD panels with color sequential display and area control," IEEE Trans. Ind. Electron., vol. 55, no. 10, pp. 3791-3800, Oct. 2008

3. H. J. Chiu, Y. K. Lo, J. T. Chen, S. J. Cheng, C. Y. Lin, and S. C. Mou, "A high-efficiency dimmable LED driver for low-power lighting applications," IEEE Trans. Ind. Electron., vol. 57, no. 2, pp. 735-743, Feb. 2010.

4. S. Y. R. Hui, S. N. Li, X. H. Tao, W. Chen, and W. M. Ng, "A novel passive off-line light-emitting diode (LED) driver with long lifetime," IEEE Trans. Power Electron., 2010.

5. K. Zhou, J. G. Zhang, S. Yuvarajan, and D. F. Weng, "Quasi-active power factor correction circuit for HB LED driver," IEEE Trans. Power Electron., vol. 23, no. 3, pp. 1410-1415, May 2008.

6. Sureshkumar, A., Suresh, P., and Vishnuram,P "Power factor maintain for LED driver using isolated converter with soft switching," Journal of Advanced Research in Dynamical and Control Systems 10(7 Special Issue), pp. 1233-1239

7. H. J. Chiu and S. J. Cheng, "LED backlight driving system for large-scale ofLCDpanels,'IEEETrans.Ind.Electron.,vol.54,no.5,pp.2 751-2760, Oct. 2007.

8. D. G. Lamar, J. S. Zuniga, A. R. Alonso, M. R. Gonzalez, and M. M. H. Alvarez, "A very simple control strategy for power factor correctors driving high-brightness LEDs," IEEE Trans. Power Electron., vol. 24, no. 8, pp. 2032-2042, Aug. 2009.

9. L. Gu, X. Ruan, M. Xu, and K. Yao, "Means of eliminating electrolytic capacitor in AC/DC power supplies for LED lightings," IEEE Trans. Power Electron., vol. 24, no. 5, pp. 1399-1408, May 2009.

10. J. Cardesin, J. Ribas, J. Garcia-Garcia, M. Rico-Secades, A. J. Calleja, E. L. Corominas, and M. A. D. Costa, "LED permanent emergency lighting system based on a single magnetic component," IEEE Trans. Power Electron., vol. 24, no. 5, pp. 1409-1416, May 2009.

11. G. Moschopoulos and P. Jain, "Single-phase single-stage power-factor corrected converter topologies,"IEEETrans.Ind.Electron.,vol.52,no.1, pp. 23-35, Feb. 2005.

12. D. D.-C. Lu, H. H.-C. Iu, and V. Pjevalica, "Single-stage ac/dc boost- forward converter with high power factor and regulated bus and output voltages," IEEE Trans. Ind. Electron., vol. 56, no. 6, pp. 2218-2132, Jun. 2009.802

13. J.-Y.Lee,"'Single-stageac/dcconverterwithinput-currentde ad-zonecontrol for wide input voltage ranges," IEEE Trans. Ind. Electron., vol. 54, no. 2, pp. 724-732, Apr. 2007.

14. D. L. O'Sullivan, M. G. Egan, and M. J. Willers, "A family of singlestage resonant ac/dc converters with PFC," IEEE Trans. Power Electron., vol. 24, no. 2, pp. 398-408, Feb. 2009.

15. H. S. Athab and D. D.-C. Lu, "A high-efficiency ac/dc converter with quasi-active power factor correction," IEEE Trans. Power Electron., vol. 25, no. 5, pp. 1103-1109, May 2010. 
16. M.G.Egan,D. L.O’Sullivan,J. G.Hayes, M. J. Willers,and C.P.Henze,

"Power-factor-correctedsingle-stageinductivechargerforel ectricvehicle batteries," IEEE Trans. Ind. Electron., vol. 54, no. 2, pp. 1217-1226, Apr. 2007.

17. D.D.-C.Lu,H.H.-C.Iu,andV.Pjevalica,“Asingle-stageac/d cconverter with high power factor, regulated bus voltage, and output voltage," IEEE Trans. Power Electron., vol. 23, no. 1, pp. 218-228, Jan. 2008.

18. C. M. Lai and K. K. Shyu, "A single-stage AC/DC converter based on zero voltage switching LLC resonant topology," IET Elect. Power Appl., vol. 1, no. 5, pp. 743-752, Sep. 2007.

19. J. M. Alonso, M. A. D. Costa, and C. Ordiz, "Integrated buck-flyback converter as a high-power-factor off-line power supply," IEEE Trans. Ind. Electron., vol. 55, no. 3, pp. 1090-1100, Mar. 2008.

20. J. C. W. Lam and P. K. Jain, "A modified valley fill electronic ballast having a current source resonant inverter with improved line-current total harmonic distortion(THD) ,high power factor, and low lamp crest factor," IEEE Trans. Ind. Electron., vol. 55, no. 3, pp. 1147-1159, Mar. 2008.

21. S.-K. Ki and D. D.-C. Lu, "Implementation of an efficient transformer less single-stage single-switch ac/dc converter," IEEE Trans. Ind. Electron., vol. 57, no. 12, pp. 4095-4105, Dec. 2010.

22. H.-L. Cheng, Y.-C. Hsieh, and C.-S. Lin, "A novel single-stage high-power-factor ac/dc converter featuring high circuit efficiency," IEEE Trans. Ind. Electron., vol. 58, no. 2, pp. 524-532, Feb. 2011.

23. Z. Li, C.-Y. Park, J.-M. Kwon, and B.-H. Kwon, "High-power-factor single-stage LCC resonant inverter for liquid crystal display backlight," IEEE Trans. Ind. Electron., vol. 58, no. 3, pp. 1008-1015, Mar. 2011.

24. H. Ribeiro and B. Borges, "New optimized full-bridge, single stage AC/DC converters," IEEE Trans. Ind. Electron., p. 1, 2011.

25. M. A. D. Costa, J. M. Alonso, J. Cardesín, J. García, and D. G. Lamar, "A single-stage high-power-factor electronic ballast based on integrated buck flyback converter to supply metal halide lamps," IEEE Trans. Ind. Electron., vol. 55, no. 3, pp. 1112-1122, Mar. 2008.

26. C. S. Moo, K. H. Lee, H. L. Cheng, and W. M. Chen, “A single-stage high-power-factor electronic ballast with ZVS buck-boost conversion," IEEE Trans. Ind. Electron., vol. 56, no. 4, pp. 1136-1146, Apr. 2009.

27. D. Gacio, J. M. Alonso, A. J. Calleja, J. García, and M. R. Secades, "A universal-input single-stage high-power-factor power supply for HB-LEDs based on integrated buck-flyback converter," IEEE Trans. Ind. Electron., vol. 58, no. 2, pp. 589-599, Feb. 2011.

28. R. L. Lin and Y. F. Chen, "Equivalent circuit model of light-emittingdiode for system analyses of lighting drivers," in Conf. Rec. IEEE 44th IAS Annu. Meeting, 2009, pp. 1-5.

29. R. L. Lin and Y. F. Chen, "System analysis of DCM dual-loop controlled light-emitting-diode boost driver," in Conf. Rec. IEEE 44th IAS Annu. Meeting, 2009, pp. 1-6.

30. R. L. Lin and Y. F. Chen, "System analysis of CCM dual-loop controlled light-emitting-diode boost driver," in Conf. Rec. IEEE 44th IAS Annu. Meeting, 2009, pp. 1-6.

31. X. Tao and R. Hui, "Dynamic photo-electro-thermal theory for lightemitting diode (LED) systems," IEEE Trans. Ind. Electron., p. 1, 2011.

32. H. Xu, H.-J. Kim, and W.-S. Chung, "Experimental identification method for small-signal analysis of smart power ICs," IEEE Trans. Ind. Electron., vol. 57, no. 6, pp. 2142-2150, Jun. 2010

33. Luxeon K2, Technical Datasheet DS51, Philips Lumileds, San Jose, CA, Jul. 2007.
34. J. Sun and H. Grotstollen, "Averaged modeling of switching power converters: Reformulation and theoretical basis," in Proc. IEEE 23rd PESC, 1992, pp. $1162-1172$.

35. J. Sun and H. Grotstollen, "Averaged modeling and analysis of resonant converters," in Proc. IEEE 24th Power Electron. Spec. Conf., 1993, pp. 707-713.

36. J. Sun, "Unified averaged switch models for stability analysis of large distributed power systems," in Proc. IEEE 15th APEC, 2000, pp. 249-255. 